\title{
Decreased Subcutaneous Bioavailability of an Oxyntomodulin Analog in a Controlled Release Formulation could be Caused by Skin Metabolism in Rats
}

Mengmeng Wang ${ }^{1}$, David Defranco ${ }^{1}$, Katherine Wright ${ }^{1}$, Shakey Quazi ${ }^{1}$, Jianqing Chen ${ }^{1}$, Jennifer Spencer-Pierce ${ }^{1}$, Iman Zaghloul ${ }^{1}$, Roger Pak $^{2}$, Ramin Darvair ${ }^{2}$, Aadithya Krishnan ${ }^{2}$, Mylene Perreault ${ }^{3}$, Lei Sun ${ }^{1}$, Josef Ozer ${ }^{1}$ and Xin Xu ${ }^{1}$

${ }^{1}$ PDM, Pfizer, Andover, MA, United States, 01810

${ }^{2}$ PharmSci, Pfizer, Andover, MA, United States, 01810

${ }^{3}$ BioTx BRU, Pfizer, Cambridge, MA, United States, 02140

\begin{abstract}
Objectives In vivo and in vitro studies were conducted to understand the potential cause for the reduced bioavailability of Peptide $\mathrm{A}$, an Oxyntomodulin analog, following subcutaneous administration in the controlled release formulation compared to that in the instant release formulation, in spite of a prolonged half-life achieved by the controlled release formulation.

Methods Concentrations in plasma, urine, feces and/or a panel of tissues including skin were measured after intravenous or subcutaneous administration of Peptide A or [125] Peptide A to rats. Dose recovery, pharmacokinetic parameters and skin absorption kinetics were estimated. In vitro skin stability in rats was also performed for [ [125] Peptide A. HPLC radio chromatography was used to elucidate peptide degradation in skin from in vivo and in vitro studies.

Results The near complete recovery of total radioactivity after subcutaneous administration of [ $\left.{ }^{125} \mid\right]$ Peptide A excluded the possibility that the reduced exposure was due to incomplete absorption. A major degradant peak of Peptide A from HPLC radio chromatography was observed in skin samples collected from the injection site after subcutaneous administration or from in vitro skin stability study.

Conclusions An in vitro study was developed to be able to test stability of the peptide in skin. The results from both in vivo and in vitro studies suggested that degradation of Peptide A in skin during its prolonged residence at the injection site after subcutaneous administration in the controlled release formulation could potentially contribute to a decrease in subcutaneous bioavailability despite of an increased half-life. Thus, caution needs to be taken while choosing the right strategy to extend half-life.
\end{abstract}

Keywords: Peptide; Oxyntomodulin; Skin degradation; Subcutaneous bioavailability; Radioactivity

\section{Introduction}

Oxyntomodulin (OXM) is a naturally-occurring 37 amino acid peptide with a molecular weight of $4.2 \mathrm{kDa}$. It is a product of the proglucagon gene, released from the enteroendocrine L-cells of the gastrointestinal tract after the digestion, and has a dual agonistic activity on both the Glucagon-Like Peptide 1 Receptor (GLP1R) and the Glucagon Receptor (GCGR) [1]. Modulation of glucose and energy homeostasis by OXM has been shown to depend on GLP1R activation [2]. It reduced energy intake in combination with increasing energy expenditure when administered to rodents and humans [3,4]. In a rodent model of obesity, dual GLP1R/GCGR agonists can lower blood glucose, reduce food intake, and decrease body weight with prolonged duration of action and sustained efficacy with respect to equipotent GLP1R-only agonists, at equivalent doses and exposures, without a concomitant increase in the risk of hyperglycemia [5]. Thus, OXM is a therapeutic target for weight loss and/or diabetes treatment.

In plasma, OXM is susceptible to rapid enzyme degradation. Its systemic half-life in human is only 12 minutes [6]. It was shown from a clinical study using GLP-1, that blood exposure levels must be maintained to obtain an optimal therapeutic effect [7]. Thus, the clinical application of OXM is not feasible by its short duration of action and the consequent need for repeated i.v. administration, although pharmacodynamic effects were demonstrated. The development of a potent and long-acting analog(s) of oxyntomodulin has been actively pursued. It was demonstrated that modifications to the $\mathrm{N}$ terminus of OXM modulated binding to the GLP1 receptor and degradation by DPPIV, whereas modifications to the midsection modulated binding to the GLP-1 receptor and degradation by Neutral Endopeptidase (NEP) [8]. Elongation and acylation of the $\mathrm{C}$ terminus of OXM altered GLP-1 receptor binding and duration of action in vivo, which may be due to changes in peptide clearance [8]. An OXM analog, Peptide A, was developed with enhanced pharmaceutical characteristics, such as better potency and longevity with respect to effects on food intake. When administered in an instant release formulation (IRF), it has an improved half-life $\left(t_{1 / 2}\right)$ of $4 \mathrm{~h}$ after Subcutaneous (SC) injection in rats.

In the effort of prolonging the half-life of peptides, various drug delivery technologies have been developed for sustained release [9]. Sustained-release formulations are commonly used as one

*Corresponding author: Mengmeng Wang, Pfizer, PDM, One Burtt Rd Andover, MA, United States, 01810, Tel: (978) 247-3710; Fax: (978) 247-2842 E-mail:w_bessie@yahoo.com, Mengmeng.wang@pfizer.com

Received April 20, 2012; Accepted May 30, 2012; Published June 01, 2012

Citation: Wang M, Defranco D, Wright K, Quazi S, Chen J, et al. (2012) Decreased Subcutaneous Bioavailability of an Oxyntomodulin Analog in a Controlled Release Formulation could be Caused by Skin Metabolism in Rats. J Bioequiv Availab 4: 069-077. doi:10.4172/jbb.1000115

Copyright: ( 2012 Wang M, et al. This is an open-access article distributed under the terms of the Creative Commons Attribution License, which permits unrestricted use, distribution, and reproduction in any medium, provided the original author and source are credited. 
of approaches for delivering low-molecular-weight drugs. Other approaches include transdermal patches, polymeric micelles [10], complexation [11], or injectable depots such as those in which the drug is embedded in a polymeric matrix, vesicles (e.g. liposomes), biodegradable microspheres, hydrogels [12], or formation of a reversible, water insoluble complex of the protein with divalent metal cations [13] or combination of the above. In addition to improving the duration of a drug, the sustained-released formulations can also help to reducing the fluctuation between peak and trough concentrations and maintain the serum concentration relatively constant within the therapeutic window, in contrast to the PK profiles obtained in soluble solutions. Along these lines, a Controlled Release Formulation (CRF) of Peptide A was prepared in order to optimize pharmacokinetic properties for once-a-day subcutaneous (SC) dosing.

In this study, pharmacokinetics of Peptide A after SC administration in both IRF and CRF were determined in rats. While the half-life of Peptide A in CRF was much longer than that in IRF, the systemic exposure (AUC) was decreased significantly when the CRF was used. Additional in vivo and in vitro studies were conducted to investigate possible cause(s) for the decreased exposure of Peptide A in CRF.

\section{Materials and Methods}

\section{Chemicals and reagents}

Peptide A was synthesized by Thiakis PolyPeptide Group, London, UK and certified by Pfizer Analytical and Quality Services, Pearl River, NY, with a purity $>98 \%$. HPLC-grade acetonitrile was purchased from EMD Chemicals (Gibbstown, NJ), formic acid and $0.9 \%$ sodium chloride solution from Sigma-Aldrich (St. Louis, MO), and TritonX-100 from BDH Chemicals (Radnor, PA). Distilled deionized water was prepared in-house using a PURELAB Ultra Analytical water purification system (Siemens Water Technology, Warrendale, PA). Analytical grade protease inhibitor aprotinin was purchased from MP Biomedicals, LLC (Solon, OH). Control Sprague Dawley rat plasma (anti-coagulant K2 EDTA) and urine were purchased from Bioreclamation for standard, quality control and blank matrix samples. $\mathrm{Na}^{125} \mathrm{I}$, in $0.1 \mathrm{~N} \mathrm{NaOH}$, was purchased from PerkinElmer (cat\# NEZ0332). Pierce Iodination Reagent (Iodogen) was purchased from Thermo Scientific, (cat\# 28666). Sep-Pak plus C18 cartridges (WAT020515) were purchased from Waters (Medford, MA).

\section{Iodination procedure and preparation of $\left[{ }^{125} \mathrm{I}\right]$ peptide a dosing solution}

Peptide A was radiolabeled with Iodogen as an oxidizing agent according to the method described by Saha G B [14]. Briefly, approximately $100 \mu \mathrm{g}$ of Peptide A was reacted with $2 \mathrm{mCi}$ of $\mathrm{Na}^{125} \mathrm{I}$ and $25 \mu \mathrm{g}$ of Iodogen at $\mathrm{pH}$ 7.2. After 10-minute incubation at ambient temperature, the reaction was quenched by adding excess amount of sodium ascorbate $(0.2 \mathrm{~mL}, 20 \mathrm{mg} / \mathrm{mL}$ in PBS). The iodinated product was purified with a Sep-Pak C18 column. After loading the quenched reaction solution on the prebalanced Sep-Pak C18 column, the nonreacted free iodine was removed by rinsing the column with $10 \mathrm{~mL}$ of $\mathrm{H}_{2} \mathrm{O}$ followed by $10 \mathrm{~mL}$ of $5 \%$ acetonitrile in $\mathrm{H}_{2} \mathrm{O}$. The radioiodinated product was eluted with $10 \mathrm{~mL}$ of ethanol and fractionally collected. The product fractions were combined and the solvent was removed by vacuum. The radiochemical purity of the final formulated product solution was determined by a reverse phase HPLC. A yield of approximately $70 \%$ was obtained with the radiochemical purity of $>$ $99.5 \%$.
A dosing solution was prepared by mixing unlabeled test article, a trace amount of ${ }^{125}$ I-labeled test article, and a formulation buffer (PBS, $\mathrm{pH}$ 7.2). For dosing solution used in animal studies and in vitro stability tests, specific activity ranged from 0.65 to $65 \mu \mathrm{Ci} / \mathrm{mg}$, and \% free iodine, as determined by the trichloroacetic acid-precipitation (TCA) method, was $\sim 1.0-6.5 \%$.

\section{Animal studies}

Sprague-Dawley rats ( 2-month-old males with dual jugular vein catheters) were purchased from Taconic Farms, Germantown, NY, and Pfizer (previously Wyeth Research) Institutional Animal Care and Use Committee approved all aspects of these studies. All animal studies were performed in accordance with the National Institutes of Health guide for the care and use. Test article was administered via intravenous (IV) or subcutaneous (SC) route. For IV administration, the test article was administered as a single bolus dose into jugular vein via catheter. The SC dose was administered on animal's back. The dose was based on the most recent scheduled body weights, prior to dosing. For radiolabeled studies, animals were fed with $20 \mathrm{mM}$ KI water for 3 days prior to dosing.

Blood samples ( $n=3 /$ group) of approximately $500 \mu \mathrm{L}$ each were collected via catheter into pediatric plasma separator tubes containing K2-EDTA and aprotinin (Sigma) with final concentration of $500 \mathrm{KIU} /$ $\mathrm{mL}$ at pre-determined time points and centrifuged at $3000 \mathrm{x}$ g for 10 minutes at $4^{\circ} \mathrm{C}$ to obtain plasma. Aprotinin was found to stabilize Peptide A in a previous study (data not shown). To study the absorption kinetics, the skin of 1 inch in diameter at the injection site was collected at various time points after SC dosing. The skin from the distribution site, contralateral to the injection site, was also collected to estimate the distribution of [125I] Peptide A in skin and was also used to differentiate absorption and re-distribution of radioactivity at the injection site. For 0 -min time point, the injection site skin was collected immediately after SC injection and measured directly by gamma counting. Other tissue samples including liver (one lobe), kidney, spleen, whole brain, lung, muscle, small intestine and adipose were also collected at designated time points. The weights of the tissues samples were recorded. For mass-balance studies where urine and feces samples were collected, the animals were kept in metabolic cages during the time of the study for 10 days. An estimated final concentration of $500 \mathrm{KIU} / \mathrm{mL}$ of aprotinin was pre-loaded in the urine collecting tubes. Plasma and tissue samples were stored on ice for immediate Gamma-count analysis and/or HPLC chromatography for radiolabeled studies or stored in $-80^{\circ} \mathrm{C}$ until analysis by LC/MS/MS (non-radiolabeled studies).

\section{In vivo study designs}

In this investigation, 7 animal studies were performed to characterize PK profiles, tissue distribution and degradation of Peptide A in rats with different formulations. The summaries of study designs are listed in Table 1 . Study 1 was a PK and dose recovery study of [ $\left.{ }^{125} \mathrm{I}\right]$ Peptide A after IV administration in which serial plasma samples were collected at various time points up to 10 days. Urine and feces samples were also collected during the 10-day study period. In addition, all tissue samples (list of tissues mentioned in previous session) were collected at sacrifice at the end of the study. The objectives of Studies 2 and 3 were to elucidate the PK properties of Peptide A in IRF or CRF after SC dosing of $2 \mathrm{mg} / \mathrm{kg}$. Serial plasma samples were collected at various time points up to 2 and 10 days, respectively. Urine was collect during the first 2 days of the study for Study 3 and urine volumes were recorded. 
Citation: Wang M, Defranco D, Wright K, Quazi S, Chen J, et al. (2012) Decreased Subcutaneous Bioavailability of an Oxyntomodulin Analog in a Controlled Release Formulation could be Caused by Skin Metabolism in Rats. J Bioequiv Availab 4: 069-077. doi:10.4172/jbb.1000115

\begin{tabular}{|c|c|c|c|c|c|c|c|}
\hline Study\# & Test Article & Formulation & Route & $\begin{array}{c}\text { Dose } \\
(\mathrm{mg} / \mathrm{kg})\end{array}$ & $\begin{array}{c}\text { Dose vol. } \\
(\mathrm{mL} / \mathrm{kg})\end{array}$ & $\begin{array}{c}\text { Study } \\
\text { Nature }\end{array}$ & $\begin{array}{c}\text { Time } \\
(\mathrm{hr})\end{array}$ \\
\hline Study $1^{\mathrm{a}}$ & {$\left[{ }^{125}\right.$ I]Peptide A } & IR & IV & 0.5 & 1 & PK & $\begin{array}{l}0,0.083, \\
0.25,0.5, \\
1,2,3,4, \\
6,24,72 \\
\text { and } 240\end{array}$ \\
\hline Study 2 & Peptide A & IR & $\mathrm{SC}$ & 2 & 0.4 & PK & $\begin{array}{c}0.5,1,2 \\
3,4,6,8, \\
12,24,30 \\
\text { and } 48\end{array}$ \\
\hline Study 3 & Peptide A & CR & $\mathrm{SC}$ & 2 & 0.4 & PK & $\begin{array}{l}0,0.5,1, \\
2,3,4,6, \\
24,72 \text { and } \\
240\end{array}$ \\
\hline Study 4 & {$\left[{ }^{125} \mathrm{I}\right]$ Peptide A } & IR & $\mathrm{SC}$ & 2 & 0.4 & $\begin{array}{c}\text { Tissue } \\
\text { Distribution }\end{array}$ & $\begin{array}{c}0,0.5,1 \\
3 \text { and } 7\end{array}$ \\
\hline Study 5 & {$\left[{ }^{125} \mathrm{I}\right]$ Peptide A } & CR & $\mathrm{SC}$ & 2 & 0.4 & $\begin{array}{c}\text { Tissue } \\
\text { Distribution }\end{array}$ & $\begin{array}{c}0,1,6, \\
24,72 \text { and } \\
240\end{array}$ \\
\hline Study 6 & {$\left[{ }^{125} \mathrm{I}\right]$ Peptide A } & IR & $\mathrm{SC}$ & 2 & 0.4 & $\begin{array}{l}\text { Metabolite } \\
\text { Profile }\end{array}$ & 1,2 and 3 \\
\hline Study 7 & {$\left[{ }^{125} \mathrm{I}\right]$ Peptide A } & CR & $\mathrm{SC}$ & 2 & 0.4 & $\begin{array}{c}\text { Metabolite } \\
\text { Profile }\end{array}$ & 1,2 and 3 \\
\hline
\end{tabular}

aN=5 for study $1, \mathrm{~N}=3$ in study $2-7$.

Abbreviations: IR-instant release, CR-controlled release.

Table 1: Summary of in vivo Animal study designs.

Studies 4 and 5 were conducted to understand absorption kinetics/ tissue distribution after SC dosing of IRF or CRF of $\left.{ }^{[25} \mathrm{I}\right]$ Peptide A. Each animal received about $5 \mu \mathrm{Ci}$ of radiolabeled peptide. Animals were sacrificed at indicated time points, plasma and tissue samples (listed in "animal studies" session) were collected for concentration analysis. Urine and feces over the entire time of study were also collected from Study 5 to calculate the dose recovery. Studies 6 and 7 were conducted to investigate in vivo metabolic profile after IV or SC administration. In these two studies, animals received $0.5 \mathrm{mg} / \mathrm{kg}$ and 2 $\mathrm{mg} / \mathrm{kg}$ of IV and SC dose, respectively. Each animal was dosed about $100 \mu \mathrm{Ci}$ of radioactivity to enable enough counts to be detected by the radio-chromatography. Plasma samples were collected at 2 time points around $\mathrm{C}_{\max }$ that were estimated to give enough counts for radioactivity detection. Since the estimated plasma radioactivity was too low to be detected by HPLC radio-chromatography after SC dosing of the CRF even after a high dose of radioactivity administered, no metabolic profiling of plasma samples was performed for samples collected from the CRF studies.

\section{In vitro skin stability study}

In vitro skin stability study of $\left[{ }^{125} \mathrm{I}\right]$ Peptide A was performed by incubating the peptide $(2 \mu \mathrm{g} / \mathrm{mL})$ with a piece of shaved rat skin ( $\sim 1$ inch in diameter) in $1 \mathrm{~mL}$ of PBS for $0,30,60$ and $90 \mathrm{~min}$. The radioactivity was $2 \mu \mathrm{Ci} / \mathrm{mL}$ in the incubation. The boiled skin was used as a negative control. Total and TCA soluble counts of $100 \mu \mathrm{L}$ of aliquots from the incubations were measured. The percentage of TCA soluble counts to total counts of the incubation buffer was calculated. Skin samples were taken out at the end of incubation, padded dry and counted for radioactivity. Total radioactivity of the incubation (buffer + skin) was calculated and percent recovery was determined for 90 min time point. HPLC radio-chromatography was also carried out to elucidate the conversion of the parent peptide to the degradants.

\section{Gamma-count analysis of plasma, Urine, Feces and Tissue samples}

Total radioactivity in plasma samples $(20 \mu \mathrm{L}$, in duplicates) was determined by gamma counting (Model 1480 WIZARD $^{\mathrm{m}}$, Wallac Inc., Gaithersburg, MD). Equal volume $(20 \mu \mathrm{L})$ of $20 \%$ TCA was added into each serum aliquot and samples were mixed well and spun at $\sim 12000$ rpm for 10 minutes. TCA-soluble radioactivity in the supernatant was determined by gamma-counting. TCA-precipitable radioactivity $(\mathrm{cpm})$ in a given sample (Total cpm-2 x TCA-soluble cpm), the specific activity of the dosing solution (TCA-precipitable cpm per $\mathrm{mg}$ of protein), as well as dates of sample $\left(\mathrm{t}_{\mathrm{S}}\right)$ and dosing solution $\left(\mathrm{t}_{\mathrm{D}}\right)$ measurements, were used to calculated test article concentration in a given sample, using the formula:

[TCA-precipitable cpm/EXP(-0.693/60.2 x $\left.\left.\left(t_{s}-t_{d}\right)\right)\right] /[$ specific activity x sample volume].

Total radioactivity in urine, feces and tissue samples was determined by gamma counting. The quantitation of tissue concentrations was based on the total radioactivity in tissues and the specific activity of the dosing solution after a correction for half-life for ${ }^{125}$ I. Radioactive equivalent concentrations were calculated as previously described [15]. Tissue to plasma ratio (T/S) was also calculated by using the total radioactivity for both tissue and plasma samples. 
Percent dose recovery, the percent of total radioactivity recovered at the end of the study to the total radioactivity that was dosed, after $0.5 \mathrm{mg} / \mathrm{kg}$ IV dose and $2 \mathrm{mg} / \mathrm{kg}$ SC dose of [ $\left.{ }^{125} \mathrm{I}\right]$ Peptide A in the CRF was calculated. The total radioactivity was the sum of all radioactivity recovered from plasma, urine, feces and tissues. The total peptide amount in adipose, brain, kidney, liver, lung, muscle, skin, intestine and spleen were estimated by: mean concentration in tissue *\%weight of organ to body weight * $300 \mathrm{~g}$ of body weight, in which the \%weight of organ to body weight is $7,0.57,0.73,3.66,0.5,40.43,19.03,2,0.2 \%$, respectively (internal reference).

\section{Standard solution, Plasma, Urine and Skin sample preparation}

Peptide A and internal standard (structural analog of Peptide A) powders were weighed and dissolved with $0.9 \%$ sodium chloride solution to a final concentration of $1.0 \mathrm{mg} / \mathrm{mL}$. Internal standard was further diluted into $3 \%$ formic acid in acetonitrile containing $0.05 \%$ TritonX-100 to a final working concentration of $500 \mathrm{ng} / \mathrm{mL}$. Peptide A at the different concentration levels were prepared by serial dilutions of the analyte stock solution into control rat plasma or urine. To maintain peptide integrity, all working solution preparations and dilutions into plasma or urine were performed over wet ice, and all frozen study samples were thawed on ice for sample processing. Standards, quality control, blank matrix and study samples were processed for assay analysis by protein precipitation. A $50 \mathrm{~L}$ aliquot of samples was transferred onto a $150 \mu \mathrm{L}$ volume of internal standard in cold acetonitrile (ISTD working solution) in a $2 \mathrm{~mL}$ 96-deep well plate. The samples were vortexed for $\sim 2$-minutes to mix and centrifuged at $5400 \mathrm{rpm}$ for 10 minutes at $4^{\circ} \mathrm{C}$. A $100 \mu \mathrm{L}$ aliquot of the supernatant was transferred to a clean 96-well plate where $100 \mu \mathrm{L}$ of water was added for a total volume of $200 \mu \mathrm{L}$ in the well. An aliquot of $180 \mu \mathrm{L}$ of the sample was injected on the LC/MS/ MS system for sample concentration analysis.

Skin samples collected from the injection site after dosing $\left[\mathrm{I}^{125}\right]$ Peptide A was sonicated in extraction solution (3:1 (acetonitrile : water) in $3 \%$ formic acid) in a cold room (at $4^{\circ} \mathrm{C}$ ) for $1 \mathrm{hr}$ followed by incubation on ice for $1 \mathrm{hr}$. The mixture was centrifuged at $12000 \mathrm{rpm}$ for $30 \mathrm{~min}$ at $4^{\circ} \mathrm{C}$. The supernatant was concentrated by vacuum and injected on to XBridge BEH300 C4 HPLC column for further radiochromatography.

\section{Analysis method using LC/MS/MS}

The separation is conducted in 2 steps: loading of the sample on a trapping column and eluting the peaks of interest onto the analytical separation column. Trapping column is a Waters SunFire C8 $(4.6 \times 20 \mathrm{~mm} 5 \mathrm{um})$ and analytical column a Waters Acquity UPLC BEH300 C4 (2.1 x 50 mm, $1.7 \mu \mathrm{m})$. Agilent HPLC components were used for pumping and heating the analytical column; trapping pump is Agilent 1100 quaternary pump, analytical pump an Agilent $1200 \mathrm{SL}$ binary pump with TCC set to $60^{\circ} \mathrm{C}$. Valco valves were used to select flow paths for loading and eluting using Analyst 1.5.2 software for timing and control. A CTC HTS PAL autosampler equipped with the active wash option and a $250 \mu \mathrm{L}$ syringe was used to inject the samples. The system flow rate is $1.0 \mathrm{~mL} / \mathrm{min}$ in trapping mode and $0.3 \mathrm{~mL} / \mathrm{min}$ for analytical separation. The total run time with re-equilibration is 8.5 minutes.

An AB Sciex API 5000 triple-quadrupole Mass Spectrometer (MS/MS) with Turbo Ion Spray (TIS) interface ionization source operated in a positive ion mode is used to quantitate Peptide A. The ion pairs (precursor ion product ion) $\mathrm{m} / z$ 859.2 209.1 for Peptide A and $\mathrm{m} / z 719.1822 .1$ for ISTD were selected for Multiple Reaction Monitoring (MRM). A structural analog to peptide A was selected as the Internal Standard (ISTD) to correct for any extraction and analysis inconsistency. The instrument settings were optimized to maximize the response for the analyte. The turbo gas temperature is $550^{\circ} \mathrm{C}$. The flow settings of nebulizing gas (nitrogen), collision gas (nitrogen), and curtain gas (nitrogen) were 60,60 , and $35 \mathrm{~L} / \mathrm{min}$. The optimized Declustering Potential (DP), Collision Energy (CE), Collision Cell Exit Potential (CXP), and Entrance Potential (EP) were 78, 60, 10, and 13 V. All source, gas, and lens settings are identical for the ISTD with the exception of collision energy which is set at $25 \mathrm{~V}$. The dwell time is $100 \mathrm{~ms}$ for Peptide A and $50 \mathrm{~ms}$ for ISTD. Resolution settings for the quadrupoles is Q1 low and Q3 unit. The total run time for each injection is $8.5 \mathrm{~min}$, while the MS data acquisition window is started at 4 minutes post injection and kept open for $240 \mathrm{~s}$. Peak area ratios were calculated using Analyst software version 1.5.2. A calibration curve is obtained by weighed $\left(1 / x^{2}\right)$ least-squares linear regression of the peak area ratio of the analyte to the IS versus the nominal concentration $(x)$ of analyte. The lower limit of quantitation (LLOQ) is $2.5 \mathrm{ng} / \mathrm{mL}$ for plasma and $1.0 \mathrm{ng} / \mathrm{mL}$ from urine.

\section{Radio-chromatography HPLC}

Skin extracted samples were separated on a reversed-phase HighPerformance Liquid Chromatography (HPLC) Waters X Bridge BEH $300 \mathrm{C} 4(3.5 \mu \mathrm{m} 4.6 \times 100 \mathrm{~mm})$ column with an Agilent 1100 series HPLC system. The mobile phase consisted of Solvent A $(0.1 \%$ trifluoroacetic acid in water) and Solvent B ( $0.1 \%$ trifluoroacetic acid in acetonitrile). Peptides were separated at a flow rate of $1.0 \mathrm{~mL} / \mathrm{min}$ using a 25 min step gradient ranging from $2 \%$ to $15 \%$ Solvent B for 5 minutes, followed by $15 \%$ to $60 \%$ Solvent B for 15 minutes at room temperature. The eluted peptide and its degradants were detected by a radio-HPLC-detector (IN/US $\mu$ system $\gamma$-RAM model 3) as well as UV absorbance at 210 and $280 \mathrm{~nm}$.

\section{Pharmacokinetics calculations}

Non-compartmental analysis module (Model 200 for SC route and Model 201 for IV route) of the pharmacokinetic software package WinNonlin, ver. 5.1 (Pharsight, Mountain View, CA) was used for PK parameter calculations. A dose normalized $\mathrm{AUC}_{\text {last }}$ ratio between $\mathrm{SC}$ and IV administration was used to estimate the bioavailability (F\%) for SC route. Peptide concentrations determined by LC/MS/MS or radioactive equivalent concentrations, expressed in $\mathrm{ng}$ eq. $/ \mathrm{mL}$, were used in the PK calculation.

\section{Results}

\section{Pharmacokinetics of peptide $A$ in rats}

Pharmacokinetics of Peptide A was determined in Sprague-Dawley rats following a single IV or SC dose of Peptide A or [ $\left.{ }^{125} \mathrm{I}\right]$ Peptide A. The concentration time profiles are illustrated in Figure 1. After a $0.5 \mathrm{mg} / \mathrm{kg}$ IV dose (Study 1), the radioactive equivalent (RE) plasma concentrations of $\left.{ }^{[125} \mathrm{I}\right]$ Peptide A declined bi-exponentially and the concentrations were below detection limit after $24 \mathrm{hr}$. The elimination $\mathrm{t}_{1 / 2}$ and clearance (CL) were $2.9 \mathrm{hr}$ and $30 \mathrm{~mL} / \mathrm{hr} / \mathrm{kg}$, respectively (Table 2). The RE plasma concentrations of [ $\left.{ }^{125} \mathrm{I}\right]$ Peptide $A$ at the first sampling time point after IV administration $\left(\mathrm{C}_{5 \text { min }}\right)$ was $9638 \mathrm{ng}$ eq. $/ \mathrm{mL}$ and the exposure $\left(\mathrm{AUC}_{\text {last }}\right.$ ) was $15757 \mathrm{ng}$ eq $\mathrm{hr} / \mathrm{mL}$, respectively (Table 2 ). The volume of distribution (Vss) was $68 \mathrm{~mL} / \mathrm{kg}$, which indicates that the peptide is mostly constrained in circulation. After a single $2 \mathrm{mg} / \mathrm{kg} \mathrm{SC}$ dose of Peptide A (Studies 2 and 3), the mean serum concentrations in 
IRF decreased with a slope similar to that after IV dosing (Figure 1A), suggesting that the absorption was not likely to be a rate-limiting step for the IRF. But the mean concentrations in CRF remained relatively constant to $48 \mathrm{hr}$ and followed by a steep drop (Figure 1B). Mean Cmax and $\mathrm{AUC}_{\text {last }}$ were 1835 and $160 \mathrm{ng} / \mathrm{mL}$, and 9653 and $5506 \mathrm{ng} \mathrm{x} \mathrm{hr} / \mathrm{mL}$, for IRF and CRF, respectively. The $\mathrm{AUC}_{\text {last }}$ after SC dosing of CR was statistically lower than that after dosing of IR $(\mathrm{p}=0.05)$. The apparent terminal $\mathrm{t}_{1 / 2}$ was 4.7 and $10 \mathrm{hr}$, respectively, suggesting that a prolonged $\mathrm{t}_{1 / 2}$ was achieved by the CRF. The $\mathrm{C}_{\max }$ after SC dose in IRF was observed at $1.3 \mathrm{hr}$ after drug administration and the $\mathrm{T}_{\max }$ for the CRF after SC dosing was much later with average of $10 \mathrm{hr}$, indicating a prolonged release of Peptide A from the dosing site. The Bioavailability (BA) after SC dose of IRF and CRF were $15 \%$ and $9 \%$, respectively. In all urine samples analyzed from Study 2 and 3, no intact Peptide A was detected.

\section{Rat tissue distribution of $\left[{ }^{125} \mathrm{I}\right]$ peptide $\mathrm{A}$}

After $2 \mathrm{mg} / \mathrm{kg}$ SC administration of [ $\left.{ }^{125} \mathrm{I}\right]$ Peptide A, a panel of tissues other than skin were collected that included: liver (one lobe), kidney, spleen, whole brain, lung, muscle, small intestine and adipose. The tissue concentrations increased to reach a $\mathrm{C}_{\max }$ at around $24 \mathrm{hr}$ and followed by a decline through the end of the study (Figure 3). The concentration-time profiles of the tissue panel were almost parallel with each other indicating that the tissue distribution reached steady state and there's no accumulation in the tissues collected. The tissue to serum concentration ratio ( $\mathrm{T} / \mathrm{S}$ ratio) at $24 \mathrm{hr}$ post-dose ranged from 1.6 in small intestine as the highest to 0.07 in brain as the lowest (Table 3 ). The tissue distribution pattern was similar as our historical tissue distribution pattern for biologics.

\section{Dose recovery of $\left[{ }^{125} \mathrm{I}\right]$ peptide $A$ after IV and SC administration}

After IV administration of [ $\left.{ }^{125} \mathrm{I}\right]$ Peptide A and SC dosing of [125 I] Peptide A in the CRF to rats, total radioactivity was measured in plasma, urine, feces and a panel of tissue samples up to 10 days to calculate dose recovery. About $90 \%$ and $97 \%$ of radioactivity was recovered (Table 4 ) in these two studies, in that $85 \%$ and $95 \%$ of total radioactivity was recovered in urine after IV and SC doing, respectively. Majority of the
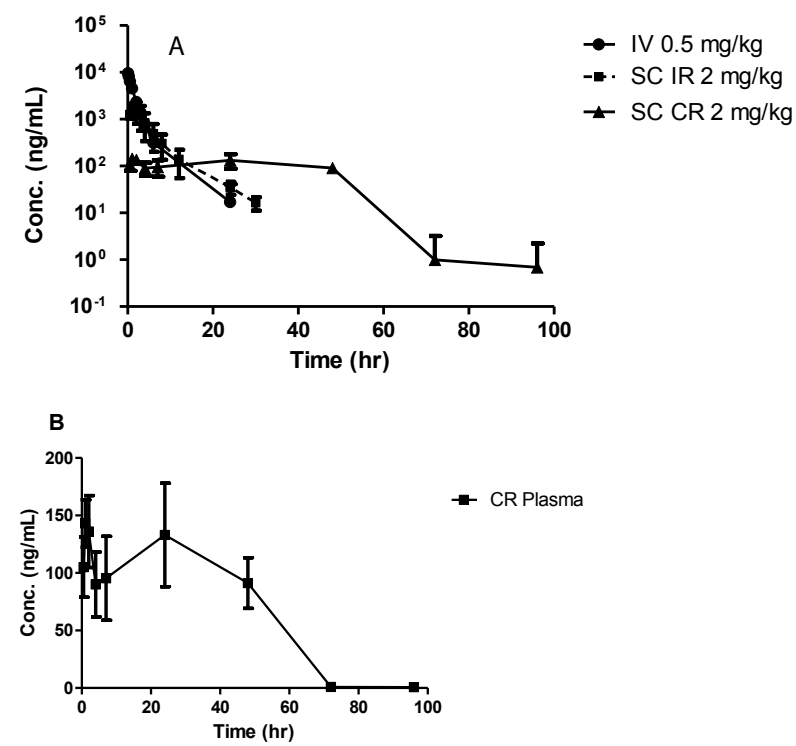

Figure 1: Rat plasma PK profiles after $0.5 \mathrm{mg} / \mathrm{kg}$ IV and/or $2 \mathrm{mg} / \mathrm{kg}$ SC dosing in IRF or CRF plotted in log scale (A) and linear scale (B). Each symbol with bar represents mean $\pm S$.D, $n=5$ for IV group and $n=3$ for SC groups.
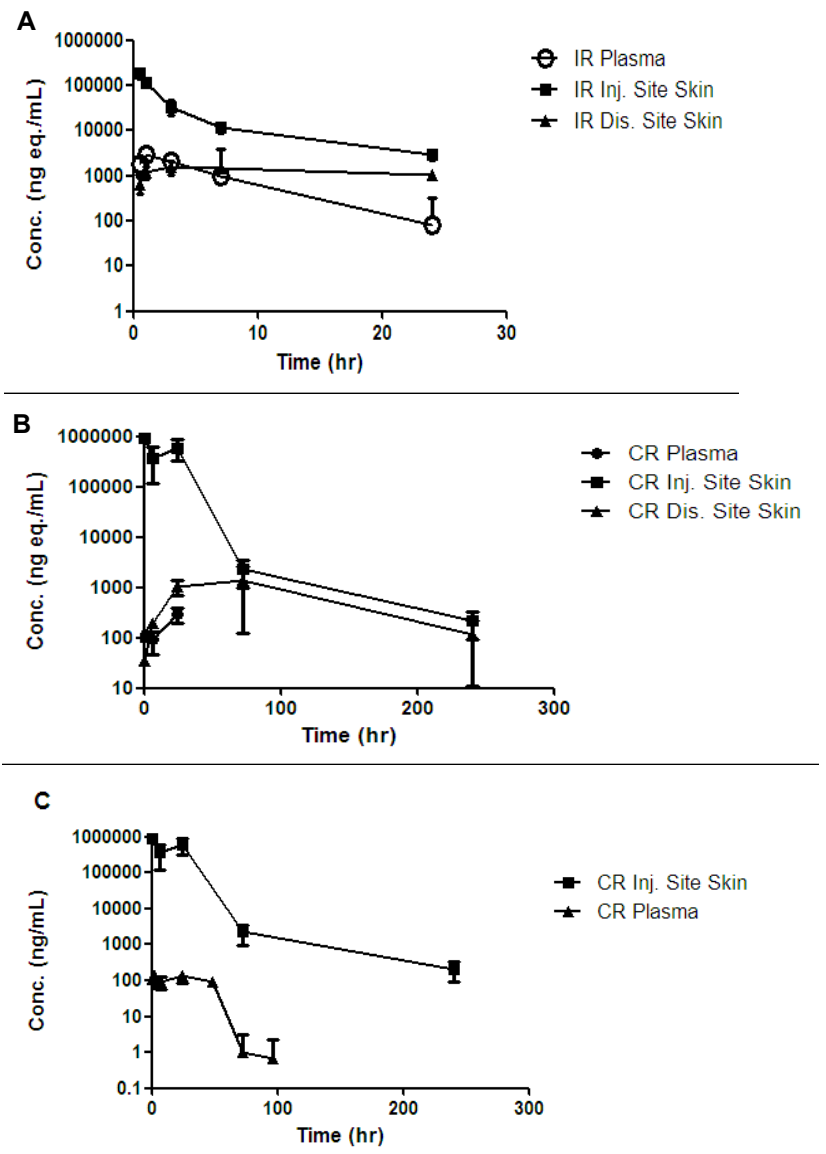

Figure 2: Concentration-time profile of [ $\left.{ }^{125}\right]$ Peptide $A$ in plasma, skin at injection and distribution sites after $2 \mathrm{mg} / \mathrm{kg}$ SC dosing of IRF (a) or CRF (b). Each symbol with bar represents mean \pm S.D, $n=5$ for IV group and $n=3$ for SC groups. Figure (c) is the comparison of concentration profile of skin at injection after SC dosing of [ $\left.{ }^{125} \mathrm{I}\right]$ Peptide A in CRF and that of plasma after SC dosing of Peptide $A$ in CRF.

counts in urine were TCA-soluble counts, indicating the degraded form(s) of Peptide A, which is consistent with the results of no parent peptide detected in urine based on LC/MS analysis.

\section{Concentration of $\left[{ }^{125} \mathrm{I}\right]$ peptide $\mathrm{A}$ in skin at injection site and distribution site}

To study the absorption kinetics, the skin at both injection site and distribution site were collected (1-inch in diameter) and measured by gamma counting. When the skin at injection site was collected right after SC dosing, the radioactivity was comparable to the total radioactivity dosed, which validated the sample collection method. After SC dosing of $\left.{ }^{[25} \mathrm{I}\right]$ Peptide A in the IRF, the concentration of $\left.{ }^{125} \mathrm{I}\right]$ Peptide A at injection site declined bi-exponentially, possibly consisting of an initial rapid absorption phase into the systemic circulation, followed by a slower release phase that was in parallel to the concentration curve in plasma (Figure 2). At 24 , only $1.6 \%$ of injected radioactivity remained at the injection site. These data indicated that the absorption of Peptide A after SC administration in the IRF was fast and complete. The re-distribution of radioactivity to skin after absorption appeared to be substantial, as measured by the radioactivity in skin samples at distribution site. The AUC ratio based on total radioactivity of distal skin site to plasma was 0.76 . 


\begin{tabular}{cccccccccccc}
\hline Study \# & Test Article & Formulation & Route & $\begin{array}{c}\text { Dose } \\
(\mathbf{m g} / \mathbf{k g})\end{array}$ & $\begin{array}{c}\mathrm{C}_{\max } \\
(\mathrm{ng} / \mathrm{mL})\end{array}$ & $\begin{array}{c}\mathrm{T}_{\max } \\
(\mathrm{hr})\end{array}$ & $\begin{array}{c}\mathrm{t}_{1 / 2} \\
(\mathrm{hr})\end{array}$ & $\begin{array}{c}\mathrm{AUC}_{\text {last }} \\
(\mathrm{hr} * \mathrm{ng} / \mathrm{mL})\end{array}$ & $\begin{array}{c}\mathrm{CL} \\
(\mathrm{m} / \mathrm{hr} / \mathrm{kg})\end{array}$ & $\begin{array}{c}\mathrm{Vss} \\
(\mathrm{mL} / \mathrm{kg})\end{array}$ & $\begin{array}{c}\mathrm{F} \\
(\%)\end{array}$ \\
\hline Study 1 & {$[\mathrm{I}-125]$ Peptide A } & $\mathrm{IR}$ & $\mathrm{IV}$ & 0.5 & $9638 \pm 403$ & $\mathrm{NA}$ & $2.9 \pm 2.2$ & $15757 \pm 262 \xi$ & $30 \pm 6$ & $68 \pm 15$ & $\mathrm{NA}$ \\
Study 2 & Peptide A & $\mathrm{IR}$ & $\mathrm{SC}$ & 2 & $1835 \pm 528$ & $1.3 \pm 0.6$ & $4.7^{\mathrm{a}}$ & $9653 \pm 4093$ & NA & NA & 15 \\
Study 3 & Peptide A & $\mathrm{CR}$ & $\mathrm{SC}$ & 2 & $160 \pm 24$ & $10 \pm 12$ & $10^{\mathrm{a}}$ & $5506 \pm 1144$ & NA & NA & 8.7358 \\
\hline
\end{tabular}

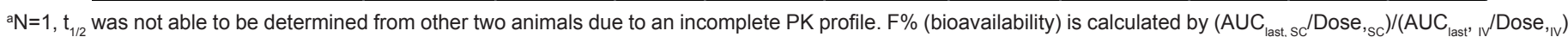
Table 2: Rat PK parameters after IV and SC administration $(n=3)$.

\begin{tabular}{ccccccccc}
\hline Tissue/serum & adipose & brain & kidney & liver lobe & lungs & muscle & $\begin{array}{c}\text { small } \\
\text { intestine }\end{array}$ & spleen \\
\hline $\mathbf{2 4} \mathbf{~ h r}$ & $0.24 \pm 0.09$ & $0.07 \pm 0.01$ & $1.7 \pm 0.3$ & $0.8 \pm 0.2$ & $0.5 \pm 0.2$ & $0.24 \pm 0.02$ & $1.6 \pm 0.5$ & $0.8 \pm 0.2$ \\
\hline
\end{tabular}

Table 3: Rat tissue to serum concentration ratio at $6 \mathrm{hr}$ and $24 \mathrm{hr}$ post $2 \mathrm{mg} / \mathrm{kg} \mathrm{SC}$ administration of CR formulation.

After SC dosing of [ $\left.{ }^{125} \mathrm{I}\right]$ Peptide A in the CRF, the concentration at injection site remained high for $48 \mathrm{hr}$, then dropped rapidly with the terminal phase parallel with that of distribution site. The absorption was complete around $72 \mathrm{hr}$ where only $0.4 \%$ of injected radioactivity remained at the injection site. Such profiles indicated that [25I] Peptide A in the CRF was slowly released from the injection site, demonstrating the anticipated "de-pot" effect for the CRF. The similar terminal slope of concentrations in all skin samples suggested that the radioactive equivalent concentrations at both distribution and injection sites reached equilibrium at later time points. Since there were only three time points (up to $24 \mathrm{hr}$ ) with detectable plasma concentration after SC dosing of the CRF, the plasma AUC was not calculated. However, the redioequivalent concentrations measured were comparable to that observed in the PK studies (Studies 2 and 3), suggesting a consistency across studies, The concentration ratio (based on total radioactivity) between skin at the distribution site and plasma was 0.45 and 0.93 at 6 and $24 \mathrm{hr}$, respectively, which was very similar to the ratio observed post IRF dosing.

\section{Skin stability study of $\left[{ }^{125} \mathrm{I}\right]$ peptide A}

To test the stability of Peptide A at the injection site, $\left[{ }^{125} \mathrm{I}\right]$ Peptide A was incubated with a piece of shaved rat skin (1-inch in diameter) at $37^{\circ} \mathrm{C}$. Boiled skin with the same size was used as a negative control assuming all enzymes related activities were quenched. The recovery of total radioactivity (incubation buffer and skin samples) after 90 min incubation was about $85 \%$ in both fresh and boiled skin samples (Table 5). The total radioactivity in the incubation buffer after 90 min incubation decreased $32 \%$ and $57 \%$ in fresh and boiled skin, respectively (Figure 4). The decrease of the total counts can be due to the distribution and non-specific binding to the skin samples. At 90 mins, the TCA soluble counts were $34 \%$ and $3 \%$ of total counts in incubation with fresh and boiled skin, respectively (Table 5), suggesting formation of degradants of Peptide A in fresh skin incubation, but not in the boiled skin incubation.

\section{HPLC radiochromatogram of in vitro and in vivo samples}

Incubation media from the skin stability study was analyzed by a reverse phase HPLC quipped with a gamma detector. At time 0 for the incubation, only one peak was detected in the radio chromatogram, which eluted at around 16 mins that corresponded to the intact peptide. The similar chromatograph was observed after 90 mins incubation with the boiled skin, indicating minimum degradation (Figure 5a), which was consistent with the low TCA-soluble counts measured in these samples. In the incubation medium samples collected at 90 -minutes

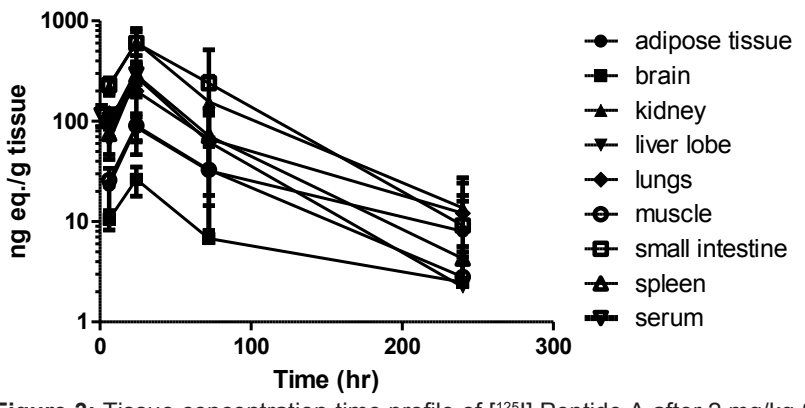

Figure 3: Tissue concentration-time profile of [125] Peptide A after $2 \mathrm{mg} / \mathrm{kg}$ SC administration of $\mathrm{CR}$ formulation.

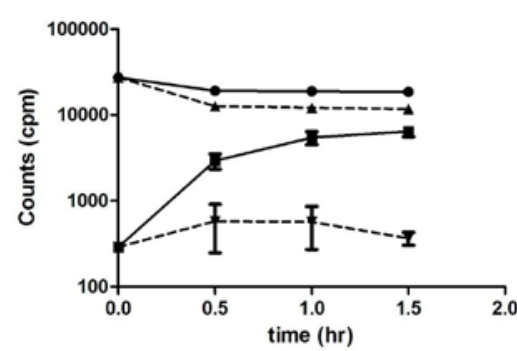

- Fresh Skin Total Counts

- Fresh Skin TCA soluble counts

-. Boiled Skin Total Counts

- Boiled Skin TCA soluble counts

Figure 4: Radioactivity of $\left.\left[{ }^{125}\right]\right]$ Peptide A in buffer after incubation with freshly cut or boiled skin.

after incubation with the fresh rat skin, the peak that corresponded to the intact peptide on the radio chromatogram decreased dramatically and another peak (M1) that eluted around 3 mins appeared (Figure 5b), suggesting the formation of Peptide A degradant(s). The skin samples collected at 30 mins post $\mathrm{SC}$ dosing of [ $\left.{ }^{125} \mathrm{I}\right]$ Peptide A in the IRF was also extracted and analyzed by HPLC. Both peaks at 3 and 16 mins were detected for the skin sample (Figure 5c).

Animal studies with high radioactivity dosed via IV or SC route in the IRF were conducted to elucidate the degradant profile in plasma (Study 6 and 7). At 5 mins, $1 \mathrm{hr}$ and $3 \mathrm{hrs}$ after IV dosing of $\left[{ }^{125} \mathrm{I}\right]$ Peptide A, only one peak at retention time of 16 mins was observed in plasma (Figure 6a). However, in samples collected at $1 \mathrm{hr}$ post SC dose with the IRF, M1 peak at 3 mins was observed in the radio chromatogram (Figure $6 \mathrm{~b}$ ). In the $3 \mathrm{hr}$ post dose plasma sample, the parent peptide peak at 16 mins decreased, while the M1 peak at 3 mins was not detected (Figure 6b). The absence of the M1 peak in the $3 \mathrm{hr}$ 
Citation: Wang M, Defranco D, Wright K, Quazi S, Chen J, et al. (2012) Decreased Subcutaneous Bioavailability of an Oxyntomodulin Analog in a Controlled Release Formulation could be Caused by Skin Metabolism in Rats. J Bioequiv Availab 4: 069-077. doi:10.4172/jbb.1000115

\begin{tabular}{lcccc}
$\begin{array}{l}\text { \%Dose } \\
\text { Recovery }\end{array}$ & \multicolumn{2}{c}{ IV $0.5 \mathrm{mg} / \mathrm{kg}$} & $\mathrm{SC}(\mathrm{CR}) 2 \mathrm{mg} / \mathrm{kg}$ \\
\hline & Ave. & Stdev & Ave. & Stdev \\
Tissue & 2.1 & 0.7 & 1.4 & 0.9 \\
Urine & 85 & 6.8 & 95 & 16 \\
Fece & 2.5 & 5.4 & 0 & 0.1 \\
\hline Total & 90 & 6.1 & 97 & 16 \\
\hline
\end{tabular}

Table 4: Percent dose/radioactivity recovery after $0.5 \mathrm{mg} / \mathrm{kg} \mathrm{IV}$ dose and $2 \mathrm{mg} /$ $\mathrm{kg} \mathrm{SC}$ dose of $\left[{ }^{125} \mathrm{l}\right]$ Peptide A in the CR formulation.

\begin{tabular}{cccc}
\hline Samples & Time $(\mathrm{min})$ & Fresh Skin & Boiled Skin \\
\hline & 0 & 1 & 1 \\
\%TCA/total counts in & 30 & 15 & 5 \\
incubation buffer & 60 & 29 & 5 \\
& 90 & 35 & 3 \\
\hline \%Recovery at 90 min & 90 & 86 & 84 \\
\hline
\end{tabular}

Table 5: Percentage of TCA soluble counts to total counts in incubation buffer, and $\%$ recovery after 90 minutes incubation of $\left[{ }^{1251}\right]$ Peptide $A$ with fresh or boiled rat skin.

sample after SC administration was very likely due to the overall low drug concentration in the sample.

\section{Discussion}

In this report, it was found that the half-life was significantly increased in rats after SC injection of Peptide A in a controlled release formulation than in an instant release formulation. However, the AUC value decreased about $50 \%$ from the IRF to the CRF. In addition, even the SC bioavailability (BA) of Peptide A in the IRF (15\%) was lower than that reported for most of the commercial peptide drugs $[16,17]$. To investigate the cause of low BA of the IRF and the further decreased
SC BA of the CRF, a dose recovery/tissue distribtuion study of $\left[{ }^{125} \mathrm{I}\right]$ Peptide A after IV and SC was performed to assess the possibility of Peptide A remaining at the injection site without being absorbed into the circulation. The tissue distribution pattern suggested that steady-state was reached in the tissue panel that was collected and [25I] Peptide A was not accumulated in any specific tissue. It was also revealed that about $97 \%$ of total dosed radioactivity was recovered in urine after SC injection, excluding the possibility that the low BA was due to incomplete absorption or incomplete sampling duration. In the urine samples from the dose recovery study, majority of the recovered radioactivity was found as TCA-soluble counts, which was confirmed by LC/MS analytical method that no intact peptide was detected in the urine. In addition, based on our experience for biologics, the skin distribution usually is very limited with ratio of skin to plasma concentration less than $10 \%$ if the distribution is non-target mediated [15]. The redistribution of the Peptide A to skin, in this study, was significantly high with skin to plasma concentration ratio approaching 1. All the above evidences lead to a hypothesis for the low SC BA that there's possible skin metabolism at the injection site.

To test the potential skin degradation of Peptide $\mathrm{A}$, an in vitro stability study in skin using ${ }^{125} \mathrm{I}$ labeled Peptide A was performed. TCAsoluble counts in the incubation buffer increased after incubation with the fresh skin, but remained constantly minimum with the boiled skin. Consistently, a major degradant peak (M1) was found in the incubation buffer with fresh skin but not with boiled skin using the HPLC radio chromatography, presumably no enzymes were active for degradation of the peptide after the skin was boiled. M1 peak was also found in plasma samples collected $1 \mathrm{hr}$ after SC injection in the IRF, but it's not present in the plasma samples after IV injection even if the plasma concentrations are much higher after IV than SC injection. The observed

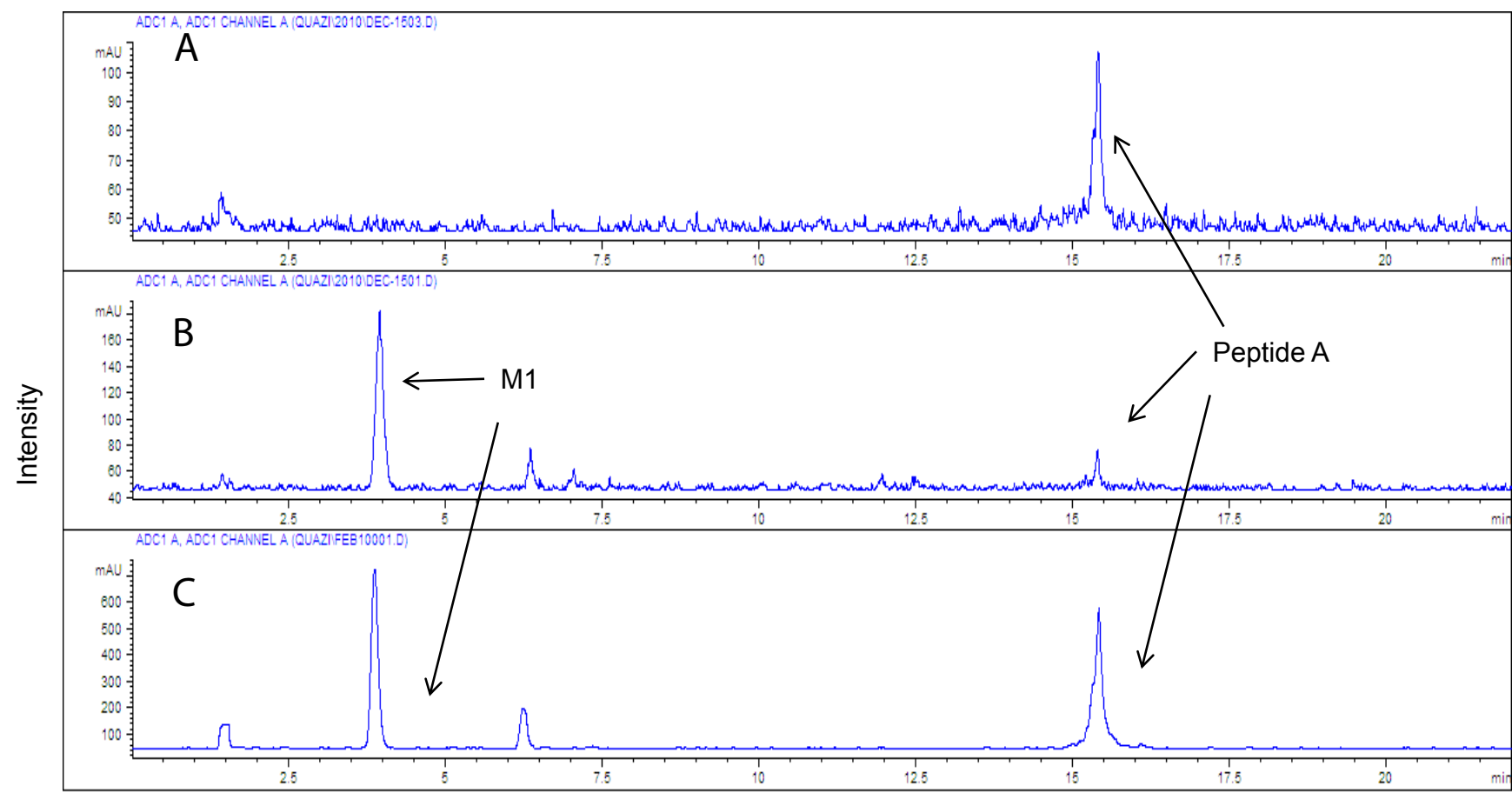

Time (min)

Figure 5: LC-Radio-chromatogram of [ $\left.{ }^{125} \mathrm{I}\right]$ Peptide A degradation in rat skin. A and B are the chromatogram of sample buffers from in vitro stability study 90 min after incubation with boiled skin (A) or fresh skin (B). C: Skin sample extract from injection site 30 min post SC dosing (2 mg/kg) of IR form to rats. 

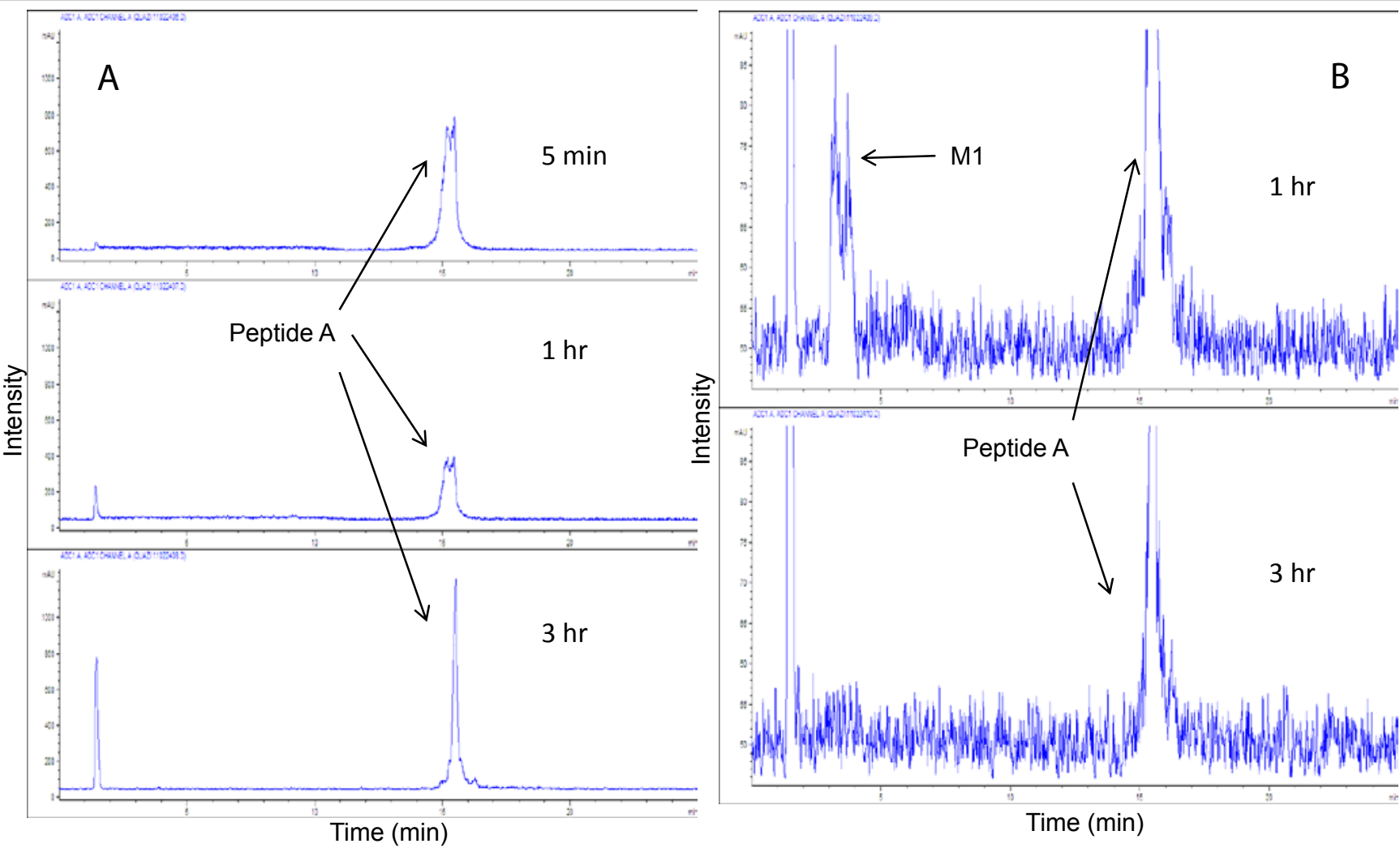

Figure 6: HPLC radio-chromatogram of [125] Peptide A in rat plasma. A: Plasma samples after $0.5 \mathrm{mg} / \mathrm{kg}$ IV administration to rats at $5 \mathrm{~min}, 1 \mathrm{hr}$ and $3 \mathrm{hr}$ post dosing. B: Plasma samples after $2 \mathrm{mg} / \mathrm{kg} \mathrm{SC}$ administration to rats at $1 \mathrm{hr}$ and $3 \mathrm{hr}$ post dosing.

formation of M1 from both in vitro and in vivo studies suggests that the degradation of $\left[{ }^{125} \mathrm{I}\right]$ Peptide A to M1 was very likely mediated via skin. Since the total plasma radioactivity dropped dramatically from $1 \mathrm{hr}$ to $3 \mathrm{hr}$ after SC administration in the IRF, M1 was not detected in $3 \mathrm{hr}$ plasma samples based on the HPLC radio chromatogram. The plasma samples collected from the CRF treatment group was not analyzed for the metabolic profiling because the radioactivity in samples was too low for the HPLC radio-chromatography.

It is also interesting to note that the total radioactivity profile at the injection site after SC dosing of radio labeled Peptide A in CRF parallels with the plasma concentrations after SC dosing of the non-radio labeled Peptide A in CRF where plasma concentrations were available at more time points by detecting with LC/MS (Figure 2c). The similar profile of the skin and plasma concentrations suggested the possible complete absorption of the peptide A into systemic circulation when it's released to free form. Both plasma and injection site concentration profiles fluctuated up to $24-48 \mathrm{hrs}$ and followed by a steeper drop with a slope very similar to the terminal elimination slope after IV dosing (Figure 2B). The fluctuation of the concentrations in the first $48 \mathrm{hr}$ could be due to the several burst of release of free peptide into the circulation. Around $48 \mathrm{hr}$ post dosing, the absorption was almost complete and the elimination rates dominated the terminal profile.

For most of the peptide drugs dosed SC, BA range from 50-80\% in both rats and human subjects. For example, insulin has 50\% BA in rat [18] and $70-80 \%$ in human, for exenatide about $62 \%$ in rat [19] and $65 \%-75 \%$ in human [16], for GLP-1 about $50-70 \%$ in rat [20] and for liraglutide about $55 \%$ in human [17]. Thus, rats could be used as a reasonable animal model to predict SC BA in human. Our study raised the possibility that the low SC BA of Peptide A in the IRF in rats can be explained by the degradation in skin at the injection site. Since the peptide in controlled release formulation is exposed to skin degradation for a longer period of time (Figure 2), the extent of conversion of the peptide to its degradant(s) is higher, resulting in a lower BA compared to that for the IRF. In fact, similarly, quantitative pharmacokinetic analysis of published insulin absorption curves for $\mathrm{SC}$ administration revealed that the relative BA of different forms of insulin could vary quite differently: The mean absorption levels for lispro insulin that is absorbed faster than the regular insulin are 70 to $80 \%$. NPH (Neutral Protamine Hagedorn), intermediate-acting insulin, has mean absorption levels of $30 \%$ or less. It is interesting to note that slower absorption rate will lead to a longer duration of insulin in skin and in turn, will lead to a lower SC BA of insulin, which is consistent with the observation from this study.

In insulin PK studies reported in the literature, some were carried out by means of external counting of radio iodinated insulin to measure the amount remaining at the injection site. These studies usually showed excellent absorption of insulin [21]. However, it was later shown that using semi synthetic $\left[{ }^{3} \mathrm{H}\right]$ insulin rather than radio iodinated insulin, a considerable amount of insulin is degraded at the injection site $[22,23]$. The complete absorption observed by external counting from the previous study was based on total radioactivity including free iodine or degraded fragments, which were completely absorbed as observed in this study. The study with semi synthetic $\left[{ }^{3} \mathrm{H}\right]$ insulin was able to detect the intact insulin, thus skin metabolism was suggested. In this study, the Peptide A concentration in plasma was 
Citation: Wang M, Defranco D, Wright K, Quazi S, Chen J, et al. (2012) Decreased Subcutaneous Bioavailability of an Oxyntomodulin Analog in a Controlled Release Formulation could be Caused by Skin Metabolism in Rats. J Bioequiv Availab 4: 069-077. doi:10.4172/jbb.1000115

measured by TCA-perceptible counts which were more representative of the intact peptides. When the plasma concentrations from the radio labeled study were compared with the concentrations measured from LC/MS analysis, similar results were observed, suggesting that the TCA-perceptible counts could represent for the intact parent peptide. However, the peptide concentrations in tissues, including skin at the injection site, were measured by total radioactivity which could be contributed by both intact peptides and the degradants. Thus, the tissue to plasma ratio should be calculated using the total counts for both skin and plasma samples in order to prevent an overestimation.

In conclusion, this study demonstrated that while controlled release formulation prolonged the systemic $t_{1 / 2}$ of the Peptide $A$, the degradation of the peptide in skin during its prolonged residence could potentially offset its systemic exposure. Thus, caution needs to be taken to balance the increase of half-life and the decrease of exposure while choosing a right formulation.

\section{References}

1. Gros L, Thorens B, Bataille D, Kervran (1993) A Glucagon-like peptide-1-(7-36) amide, oxyntomodulin, and glucagon interact with a common receptor in a somatostatin-secreting cell line. Endocrinology 133: 631-638.

2. Dakin CL, Gunn I, Small CJ, Edwards CM, Hay DL, et al (2001) Oxyntomodulin inhibits food intake in the rat. Endocrinology 142: 4244-4250.

3. Cohen MA, Ellis SM, Le Roux CW, Batterham RL, Park A, et al (2003) Oxyntomodulin suppresses appetite and reduces food intake in humans. J Clin Endocrinol Metab 88: 4696-4701.

4. Dakin CL, Small CJ, Park AJ, Seth A, Ghatei MA, et al. (2002) Repeated ICV administration of oxyntomodulin causes a greater reduction in body weight gain than in pair-fed rats. Am J Physiol Endocrinol Metab 283: E1173-E1177.

5. Pocai A, Carrington PE, Adams JR, Wright M, Eiermann G, et al. (2009) Glucagon-like peptide 1/glucagon receptor dual agonism reverses obesity in mice. Diabetes 58: 2258-2266.

6. Schjoldager BT, Baldissera FG, Mortensen PE, Holst JJ, Christiansen J (1988) Oxyntomodulin: a potential hormone from the distal gut. Pharmacokinetics and effects on gastric acid and insulin secretion in man. Eur J Clin Invest 18: 499503.

7. Larsen J, Hylleberg B, Ng K, Damsbo P (2001) Glucagon-like peptide-1 infusion must be maintained for $24 \mathrm{~h} /$ day to obtain acceptable glycemia in type 2 diabetic patients who are poorly controlled on sulphonylurea treatment. Diabetes care 24: 1416-1421.

8. Druce MR, Minnion JS, Field BC, Patel SR, Shillito JC, et al. (2009) Investigation of structure-activity relationships of Oxyntomodulin (Oxm) using Oxm analogs. Endocrinology 150: 1712-1722.

9. Putney SD, Burke PA (1998) Improving protein therapeutics with sustainedrelease formulations. Nat Biotechnol 16: 153-157.

10. Giddi HS, Arunagirinathan MA, Bellare JR (2007) Self-assembled surfactan nano-structures important in drug delivery: a review. Indian J Exp Biol 45: 133159.

11. Ye M, Bhat G, Johnston KA, Tan H, Garnick M (2006) Proprietary Rel-Ease drug delivery technology: opportunity for sustained delivery of peptides, proteins and small molecules. Expert Opin Drug Deliv 3: 663-675.

12. Garbayo E, Ansorena E, Lanciego JL, Aymerich MS, Blanco-Prieto MJ (2008) Sustained release of bioactive glycosylated glial cell-line derived neurotrophic factor from biodegradable polymeric microspheres. Eur J Pharm Biopharm 69: 844-851.

13. Coleman JE (1992) Zinc proteins: enzymes, storage proteins, transcription factors, and replication proteins. Annu Rev Biochem 61: 897-946.

14. Saha GB, Whitten J, Go RT (1989) Conditions of radioiodination with iodogen as oxidizing agent. Int J Rad Appl Instrum B16: 431-433.

15. Vugmeyster Y, DeFranco D, Szklut P, Wang Q, Xu X (2010) Biodistribution of $\left[{ }^{125}\right]$-labeled therapeutic proteins: application in protein drug development beyond oncology. J Pharm Sci 99: 1028-1045.

16. Bray GM (2006) Exenatide. Am J Health Syst Pharm 63: 411-418.

17. Clinical Pharmacology. Gold Standard, Inc.

18. Tokihiro K, Arima H, Tajiri S, Irie T, Hirayama F, et al. (2000) Improvement of subcutaneous bioavailability of insulin by sulphobutyl ether beta-cyclodextrin in rats. J Pharm Pharmacol 52: 911-917.

19. Gedulin BR, Smith PA, Jodka CM, Chen K, Bhavsar S, et al. (2008) Pharmacokinetics and pharmacodynamics of exenatide following alternate routes of administration. Int J Pharm 356: 231-238.

20. Parkes D, Jodka C, Smith P, Nayak S, Rinehart L, et al. (2001) Pharmacokinetic Actions of exendin-4 in the rat:Comparison with glucagon-like peptide-1. Drug Dev Res 53: 260-267.

21. Binder C, Lauritzen T, Faber O, Pramming S (1984) Insulin pharmacokinetics Diabetes care 7: 188-199.

22. Berger M, Halban PA, Girardier L, Seydoux J, Offord RE, et al. (1979) Absorption kinetics of subcutaneously injected insulin. Evidence for degradation at the injection site. Diabetologia 17: 97-99.

23. Berger M, Halban PA, Muller WA, Offord RE, Renold AE, et al. (1978) Mobilization of subcutaneously injected tritiated insulin in rats: effects of muscular exercise. Diabetologia 15: 133-140. 